Original Research Paper

\title{
Morphological Signs of Barley Spot Pathogens in the Conditions of the Almaty Region
}

\author{
${ }^{1 *}$ Nadira Zhumakhanovna Sultanova, ${ }^{1}$ Alibek Maratovich Uspanov, ${ }^{1}$ Madina Malikovna Bekezhanova, \\ ${ }^{2}$ Alua Manatbekkyzy Rysbekova and ${ }^{1}$ Gaziza Bazarbaevna Sarsenbayeva
}

${ }^{1}$ Kazakh Research Institute for Plant Protection and Quarantine, Almaty, Kazakhstan

${ }^{2}$ Kazakh National Agrarian University, Almaty, Kazakhstan

\author{
Article history \\ Received: 30-12-2020 \\ Revised: 29-03-2021 \\ Accepted: 31-03-2021 \\ Corresponding Author: \\ Nadira Zhumakhanovna \\ Sultanova \\ Kazakh Research Institute for \\ Plant Protection and \\ Quarantine, Almaty, \\ Kazakhstan \\ Email: nadira.sultanova@mail.ru
}

\begin{abstract}
The most widespread barley diseases in the southeastern region of Kazakhstan are common root rot, dark brown spots (caused by Bipolaris sorokiniana Shoem) and stripe disease (Drechslera graminea). This study presents the results of the morphological and cultural characteristics of fungi causing these diseases. The occurrence of the B. sorokiniana, fungi on barley leaves averaged $6.5 \%$. They are more often was found with fungi from the genus Alternaria (35.5\%). The D. graminea and Alternaria were registered in $25 \%$ of the samples. The optimal nutrient media for the cultivation of $B$. sorokiniana, were namely V4 medium, potato agar and Czapek's medium. The optimal temperature for the growth of colonies of B. sorokiniana were ranged from 22 to $30^{\circ} \mathrm{C}$. D. graminea conidia isolated from natural substrates had a statistically significant increase in length, width and the number of septa compared to conidia grown on an artificial V4 nutrient medium. The germination energy of barley equaled 71-73\% for the Astana 2000, Preriya and Symbat barley varieties, $79 \%$ for the Sever variety, $88 \%$ for the Arn variety and $96-96.5 \%$ for the Donetskiy 8 and Ilek 9 varieties.
\end{abstract}

Keywords: Barley, Seeds, Bipolaris sorokiniana, Drechslera Graminea

\section{Introduction}

Spring barley is an important food crop in Kazakhstan; it is cultivated on an area of 1,881 thousand ha with an average yield of $13.1 \mathrm{c} /$ ha (FAO, IFAD, UNICEF, WFP and WHO, 2018; GRK, 2018). Usually, it is placed in a crop rotation with the 3 rd or 4 th crop after fallow ground. The yield of barley is influenced by diseases with soil infections, which include common root rot (caused by Bipolaris sorokiniana Shoem., Fusarium spp.) and dark brown leaf spot (Bipolaris sorokiniana Saccin Sorok) Shoem (Agrios, 2005). Symptoms of diseases appear on barley in the form of leaf spots and root rot on seedlings, ears, stems, leaves, parts of flowers. The yield of barley grain, in this case, decreases by $10-50 \%$. The most widespread barley diseases in the South-Eastern region of Kazakhstan are common root rot and dark brown spots (caused by B. sorokiniana), stripe disease (Drechslera graminea), net blotch (D. teres) and bordered leaf blotch (Rhynchosporium secalis) (Bekezhanova, 2009). Successful control of these diseases depends on the use of resistant varieties, seeds that are free of pathogens, seed treatment with fungicides, crop rotation and fertilization, plowing of contaminated crop residues and application of fungicides (Agrios, 2005; Lucas, 2020; Sagitov et al., 2020). Besides, phytopathogenic fungi lead to changes in various chlorophyll fractions in diseased plants (Kuldubayev et al., 2020; Dutbayev et al., 2020a-b).

Recent studies on the study of barley diseases with soil infection were carried out to develop a strategy for protecting barley seedlings from infection caused by Sclerotium rolfsii using soil infested with the antagonist fungi Trichoderma (Faruk, 2019), study the effect hydrothermal stress on the development of soil infections in wheat and barley (Toropova et al., 2018), evaluate the effectiveness of pre-sowing seed treatment against infection caused by Fusarium spp. and Cochliobolus sativus (Sooväli et al., 2017), develop protective measures (Gangwar et al., 2018; Høyer et al., 2019; Singh, 2017), identify the soil-habitat barley mosaic virus (Cadot et al., 2017) and study the antagonistic activity of bacterial species of the Bacillus genus on the B. sorokiniana barley as pathogenic fungi (Harba et al., 2020). Currently, there is no research in Kazakhstan on barley diseases with soil infection. 
The purpose of our research was to study the morphological and cultural characteristics of fungi causing barley leaf spot disease, B. sorokiniana and $D$. graminea, in the South-East of Kazakhstan. During the study, we found that the occurrence of the B. sorokiniana on barley leaves in the foothills of the Almaty region averaged $6.5 \%$, together with fungi from the genus Alternaria $(35.5 \%)$. D. graminea + Alternaria were found about $25 \%$ of the samples. We determined the optimal nutrient media for the cultivation of $B$. sorokiniana and $D$. graminea. We also established the morphological characteristics of conidia and their colonies.

\section{Methods}

When studying the biological characteristics of pathogens of dark brown and striped spots, barley was grown in soil, plastic vessels, humid chambers and artificial agar nutrient media. Barley seeds were sown in wet sand or soil filled with plastic containers to determine the extent of pathogen infestation. For these purposes, seeds were sown 3-4 cm deep in plastic cups, were kept in a laboratory in front of a window or a special flora at $15^{\circ} \mathrm{C}$ for 14-20 days (Agrios, 2005).

To isolate a pure culture of the $B$. sorokiniana, the fungi mycelium and conidia formed in leaf fragments in a humid environment were inoculated onto V4 artificial media, Czapek's medium, potato agar, oat agar containing vegetable juices and agar. They were kept in a thermostat at $22^{\circ} \mathrm{C}$ for $7-10$ days.

Then, pure cultures of the pathogen were isolated, which were cultured on V4 nutrient culture medium and incubated for 8 days at $23^{\circ} \mathrm{C}$ for $12 \mathrm{~h}$ in the light and $12 \mathrm{~h}$ in the dark (Agrios, 2005; Barbedo, 2019). Composition of V4 medium from vegetable crops: V4 Consisted of 150 $\mathrm{mL}$ of vegetable juice from the following crops: $60 \mathrm{~mL}$ of beetroot juice, $45 \mathrm{~mL}$ of celery juice, $30 \mathrm{~mL}$ of carrot juice, $15 \mathrm{~mL}$ of tomato juice, $15 \mathrm{~g}$ of agar, $3 \mathrm{~g}$ of $\mathrm{CaCO}_{3}$ and 850 $\mathrm{mL}$ of distilled water.

To determine the optimal temperature for the growth of colonies of $B$. sorokiniana isolated from pieces of barley leaves from the Almaty region, it was grown in pure V4 culture medium in petri dishes at different temperatures: $5,13-15,16-18,22,30$ and $41^{\circ} \mathrm{C}$ in four replicates. Then, on days 5, 8, 10 and 15 , the growth rate of fungal colonies was determined.

The paper roll method was used to determine the ability of transmission of pathogens of Helminthosporium spots through seeds. For this, 40 seeds were sown on two layers of sterile blotting paper $(15 \times 105 \mathrm{~cm})$ at a distance of $2 \mathrm{~cm}$. Then the paper was moistened with sterile water and covered with a second sheet of moistened paper $(5 \times 105 \mathrm{~cm})$. The bags were placed in glass or plastic containers filled with an equal amount of water and kept in a thermostat at $20^{\circ} \mathrm{C}$ for $3-4$ days. Then they were grown for 10-12 days in front of a window or an installation with special lamps. After 12-14 days, the sprouted seeds and seedlings were carefully examined for the presence of leaf spots and root rot. To determine the biometric characteristics of fungi species, the length and width of 100 conidia and the number of septa were measured (Agrios, 2005; Barbedo, 2019).

To determine the effect of different temperatures on the growth of the colonies of the $D$. graminea, we grew its culture in thermostats at $10,16,20,25,29$ and $37^{\circ} \mathrm{C}$ on the V4 artificial medium. The diameter of the fungi colonies was examined after 15 days.

The following method was used to determine the presence of Bipolaris and Drechslera in the seeds of barley varieties in the southern and southeastern regions: 25 Grains were grown in four replicates in a humid chamber at $25^{\circ} \mathrm{C}$. After seven days, they were examined and if a plaque was observed on the surface of the grain, it was cut on glass slides and the species composition of the fungi was determined under a microscope. To determine the optimal temperature required for the growth of pure cultures of the $B$. sorokiniana and D. graminea, they were cultured in four replicates of $\mathrm{V} 4$ nutrient medium in petri dishes at $3-5,13-15,16-18,22,30$ and $41^{\circ} \mathrm{C}$. Colony diameters were measured after 5, 8, 10 and 15 days (Agrios, 2005; Barbedo, 2019).

Barley seeds received from Agropark Ontustik LLP were assessed on the 3rd and 5th days and the laboratory germination was assessed on the 7th day. The sowing quality of seeds was determined in humid chambers placed in a thermostat at a temperature of $24^{\circ} \mathrm{C}$. The germination energy was taken into account on the 3 rd day after the beginning of the experiment and the laboratory germination was evaluated on the 7 th day, according to the number of germinated seeds (Barbedo, 2019).

The analysis of variance was performed using the $\mathrm{R}$ software. The acceptable level of significance was determined using the P-value (Aphalo, 2017).

\section{Results}

We studied the morphological and cultural characteristics phytopathogenic fungi $B$. sorokiniana and D. graminea caused barley leaf spots in the South-East of Kazakhstan. A pure culture was isolated, the pathogenicity of the strains was determined and the spotting pathogens were identified. During our research, we paid special attention to the biological characteristics of pathogens, methods of preservation, the spread of Helminthosporium diseases in barley, the growth and development of pathogens. This is necessary for the correct diagnosis of phytopathogens and the choice of effective ways to carry out protective measures against diseases. To do this, it is necessary to understand the biological and morphological characteristics of 
pathogens. In some cases, they may vary depending on the growing medium and growing conditions of the plant, crop varieties and affected organs attacked by the dark brown spot disease (B. sorokiniana). The occurrence of the $B$. sorokiniana on the leaves of barley growing in the foothills of the Almaty region was estimated; the average occurrence equaled $6.5 \%$. The phytopathogenic fungi was often found together with Alternaria (35.5\%). The presence of D. graminea + Alternaria was found in $25 \%$ of the samples (Table 1).

After 3-4th days, the fungi colonies began to appear on the nutrient media. The colonies were initially pale; as they grew, their color gradually became olive, dark green, rising above the substrate, thickening and becoming denser. Within 10-15th days of colonies at the optimal temperature and optimal nutrient medium, the fungi colonies spread over the entire area of the petri dishes and due to the formation of a large number of spores, the fungi colonies had a velvety, dark green, or olive color. The conidia were brown or yellow, elliptical, upright, or slightly curved. The length range conidia of the $B$. sorokiniana was $18-77,47.4 \mu \mathrm{m}$ at the average, the width ranged from $11-22,16.6 \mu \mathrm{m}$ at the average (Table 2).

\section{Effect of Different Temperatures on the Growth of the B. Sorokiniana}

The development of plant infectious diseases is directly related to environmental conditions, especially temperature and humidity. These factors directly affect the growth of pathogenic spores and conidia, the penetration of their tubules into plant cells, as well as the spread and development of diseases. Therefore, it is important to know the optimal temperature for the growth of pathogens and its low and high values (Agrios, 2005).

During the experiment, it was found that the optimal temperature for the growth of fungi colonies ranged from 22 to $30^{\circ} \mathrm{C}$. It was found that different temperatures significantly affected the growth rate of $B$. sorokiniana colonies, as well as the morphological features of their development. At low temperatures $\left(5^{\circ} \mathrm{C}\right)$ the colonies were light gray and at high temperatures $\left(22^{\circ} \mathrm{C}\right)$ they became dense, velvety, dark brown-olive, or dark brown. At a temperature of $16-18^{\circ} \mathrm{C}$, the center of the colonies became denser, gray and the edges were pale olive, with clearly visible circles. At $22^{\circ} \mathrm{C}$, the edges of the colonies resembled the crown of carnation petals. The fungi grew very quickly at $30^{\circ} \mathrm{C}$; therefore, in 7-8 days it covered the entire petri dish and the airy fibers looked like gray wool. To determine the sowing characteristics and variability of the $B$. sorokiniana substrate isolated from barley, the phytopathogenic fungi isolate from the Almaty region was grown on V4 agar medium, Czapek's medium and nutrient media containing boiled potatoes and oats at a temperature of $25^{\circ} \mathrm{C}$. After $15-20$ days, the sowing properties and diameter of the fungi growing on various nutrient media, as well as the biometric parameters of its conidia, were determined (Fig. 1).
There was a rapid growth of colonies of phytopathogenic fungi $B$. sorokiniana on a V4 nutrient medium prepared based on several vegetable juices and artificial nutrient media containing potatoes. The fungi also grew well on Czapek's nutrient medium, where the mycelium filaments were very dense and the edges were uneven. However, the growth of the fungi on oat agar was slow and the mycelium filaments were very thin. As for the biometric parameters of fungal conidia, their length and width were significantly higher in the V4 culture compared to other media (Table 3 and Fig. 2).

\section{Barley Stripe Disease (D. graminea)}

Barley leaves with stripe disease were collected at KazNIIZiKR in 2020. First, we examined them under a microscope to find fungi spores. When moistened, a plaque was formed from conidia and conidiophores of the D. graminea. The conidia had a cylindrical shape, slightly rounded at the ends, colorless, with light yellow or light brown scales (Fig. 4). Micrometric measurements showed that the length of the conidia ranged from 46 to $150 \mu \mathrm{m}$ and the width from 11 to 25 $\mu \mathrm{m}$, with the number of septa from 1 to 5 .

In dry weather, spore-forming organs of the pathogen did not form on leaves with stripe disease. When plant samples were kept in petri dishes in a humid environment for about a week, the size of the fungi was observed to be $0.3 \mathrm{~mm}$. Taking into account that the biometric parameters of microorganisms change depending on the nutrient medium, conidia of the $D$. graminea were isolated from leaves in a humid medium on petri dishes and seeds using the paper roll method (Fig. 3). Further, a pure culture of the fungus was cultivated on a V4 nutrient medium.

It was found that conidia of the phytopathogenic fungi $D$. graminea isolated directly from natural substrates (leaves and grains) had a statistically significant greater length, width and the number of septa in comparison with conidia grown on the V4 artificial nutrient medium (Table 4).

\section{Physiological and Biological Characteristics of the D. graminea}

At a temperature of $10^{\circ} \mathrm{C}$, the colonies grew slowly and after 15 days the diameter of the plant barely reached $40 \mathrm{~mm}$. The structure of the colony was uneven. It was established that the optimum temperature for the growth of fungi was in the range of $20-30^{\circ} \mathrm{C}$. On day 10 th, the fungi colonies were completely covered in the petri dish. Morphological and seeding differences were observed in the growth of the fungi at different temperatures. On day 10 th, when cultivating $D$. graminea at $10^{\circ} \mathrm{C}$, the air mycelium of the fungi was whitish, purple and slightly elevated. The structure of the colony was even. The substrate mycelium was pale, the circle barely visible. The 
sexual reproduction organs (fruiting bodies) were not formed. When cultivating fungi at $20^{\circ} \mathrm{C}$ on the 10 th day, the air mycelium of the fungi was curly, light gray. The substrate mycelium was light gray, olive in color, without rounding. The sexual reproduction organs of fungi (fruiting bodies) were formed. When cultivating fungi at $25^{\circ} \mathrm{C}$ on the 10 th day, the air mycelium of the fungi was loose, of light gray, olive color. The substrate mycelium was light gray, olive and brown in the middle. The sexual reproduction organs of fungi (fruiting bodies) were formed (Table 5).

Barley seeds from the Almaty region were infested with B. sorokiniana, D. teres and D. graminea. The seed population was affected by both variety and infection factors. Most of the seeds were populated by the $B$. sorokiniana and $D$. graminea fungi. The Donetskiy 8 variety was the least populated with phytopathogenic infection $(27 \%)$, while other varieties were infested with it by $60-84 \%$.

The most diseased seeds were infested with $B$. sorokiniana. As a result of the analysis of variance, it was found that on days 3 and 5, the average germination energy in the groups was not equal $(\mathrm{P}$-value $=0.01)$. In the Astana 2000, Preriya and Symbat varieties on day 7, it equaled $71-73 \%$, in the Severny variety, it was $79 \%$, in the
Arna variety, it amounted to $88 \%$ and in the Donetskiy 8 and Ilek 9 varieties, it was at the level of $96-96.5 \%$.

According to the laboratory germination parameter $(\mathrm{P}$-value $=0.03)$, the average values in the groups were also not equal. In Astana 2000, it was 92\%, in Symbat and Arna it amounted to 93-94\%, in Symbat and Arna it equaled 93-94\%, in Preriya, Donetskiy 8, Severny 1 varieties it was $96-96.5 \%$ and Ilek 9 had the maximum level of $100 \%$ (Table 6).

The seed population was affected by both variety and infection factors. In the Donetskiy 8 variety, the proportion of diseased seeds was $27 \%$, in Sever 1 and Ilek 9, it equaled $59-63 \%$, in Astana 2000 and Preriya, it amounted to $68-74 \%$ and in Symbat and Arna, it was $82-84 \%$.

Table 1: Isolation of pathogens of Helminthosporium diseases from barley samples (Kazakh Scientific Research Institute of agriculture and Crop Production (KazNIIZiR) Zhalpaksay, 2020

\begin{tabular}{ll}
\hline & Number of \\
Fungi & samples, $(\%)$ \\
\hline Alternaria+ B. sorokiniana & 35.0 \\
B. sorokiniana & 6.5 \\
D. graminea + Alternaria & 25.0 \\
$P$-value at $99 \%$ confidence interval & $<0.01$ \\
\hline
\end{tabular}

Table 2: Biometric parameters conidia of the B. sorokiniana isolated from barley plants KazNIIZiR, Zhalpaksay, 2020

\begin{tabular}{lccc}
\hline Statistical indicators & Length, $\mu \mathrm{m}$ & Width, $\mu \mathrm{m}$ & Number of partitions, pieces \\
\hline Average & 99.7 & 15.6 & 6.1 \\
Median & 111.0 & 16.0 & 6.0 \\
1st quartile & 87.3 & 12.0 & 5.0 \\
3rd quartile & 118.0 & 18.2 & 7.2 \\
Minimum & 39.0 & 5.0 & 2.0 \\
Maximum & 125.0 & 13.0 & 13.0 \\
\hline
\end{tabular}

Table 3: Growth of colonies of the B. sorokiniana on various artificial nutrient media Kazakh Research Institute of Plant Protection and Quarantine, 2019

\begin{tabular}{|c|c|c|c|c|c|}
\hline \multirow[b]{2}{*}{ Nutrient medium } & \multirow{2}{*}{$\begin{array}{l}\text { Colony diameter } \\
(\mathrm{mm})\end{array}$} & \multicolumn{2}{|l|}{ Conidium } & \multicolumn{2}{|l|}{ Morphological features of the fungi } \\
\hline & & Length $(\mu \mathrm{m})$ & Width ( $\mu \mathrm{m})$ & Aerial mycelium & Substrate \\
\hline$\overline{V_{4}}$ & 850 & 850 & 18 & $\begin{array}{l}\text { Grows quickly, the surface is loose, } \\
\text { velvety, dark brown, with smooth } \\
\text { edges }\end{array}$ & $\begin{array}{l}\text { Black color, no radial lines } \\
\text { and circles are observed }\end{array}$ \\
\hline $\begin{array}{l}\text { Czapek's nutrient } \\
\text { medium }\end{array}$ & 850 & 710 & 15 & $\begin{array}{l}\text { Grows well, shades of gray or dark } \\
\text { olive or green, uneven edges }\end{array}$ & $\begin{array}{l}\text { Gray, gray-black, no radial } \\
\text { lines or circles }\end{array}$ \\
\hline Potato agar & 850 & 730 & 17 & $\begin{array}{l}\text { Grows intensively, the surface is } \\
\text { velvety, dark olive green, with } \\
\text { uneven edges }\end{array}$ & $\begin{array}{l}\text { gray-black, no radial lines or } \\
\text { circles }\end{array}$ \\
\hline Oat agar & 850 & 710 & 16 & $\begin{array}{l}\text { Grows poorly, cobweb mycelium, } \\
\text { light gray, smooth edges }\end{array}$ & $\begin{array}{l}\text { Radiality and zoning are } \\
\text { pronounced }\end{array}$ \\
\hline $\begin{array}{l}\text { P-value at } 95 \% \\
\text { confidence interval }\end{array}$ & 0.01 & 0.03 & & & \\
\hline
\end{tabular}

Table 4: Biometric indicators of D. graminea conidia Kazakh Research Institute of Plant Protection and Quarantine, 2019

\begin{tabular}{|c|c|c|c|c|c|c|}
\hline \multirow[b]{2}{*}{ Conidia isolated from } & \multicolumn{2}{|l|}{ Length $(\mu \mathrm{m})$} & \multicolumn{2}{|l|}{ Width $(\mu \mathrm{m})$} & \multicolumn{2}{|c|}{ Number of septa } \\
\hline & Mean range & Average value & Mean range & Average value & Mean range & Average value \\
\hline Leaves & $37-106$ & 74.30 & $11-25$ & 17.40 & $1-5$ & 3.60 \\
\hline Grains & $46-116$ & 82.70 & $16-21$ & 17.30 & $1-5$ & 3.40 \\
\hline $\mathrm{V}_{4}$ nutrient medium & $32-85$ & 66.70 & $14-18$ & 16.00 & $1-4$ & 2.60 \\
\hline P-value at $95 \%$ confidence interval & & 0.04 & & 0.02 & & 0.01 \\
\hline
\end{tabular}


Table 5: Sowing and morphological characteristics of the D. graminea at different temperatures Kazakh Research Institute of Plant Protection and Quarantine, 2019

\begin{tabular}{lll}
\hline & Temperature $\left({ }^{\circ} \mathrm{C}\right)$ and description & 20 \\
Parameters & 10 & even \\
Organ & uneven & Wavy, light grey \\
\hline $\begin{array}{l}\text { Aerial mycelium } \\
\text { Substrate mycelium }\end{array}$ & Whitish, purple, slightly raised & Light gray, olive color, \\
Fruiting body & Pale, barely visible circle & without rounding \\
& not formed & formed
\end{tabular}

Table 6: Results of laboratory seed germination and the intensity of settlement by Helminthosporium Kazakh Research Institute of Plant Protection and Quarantine, 2020

\begin{tabular}{|c|c|c|c|c|c|c|c|}
\hline \multirow[b]{2}{*}{ Variety } & \multicolumn{2}{|c|}{$\begin{array}{l}\text { The energy of } \\
\text { germination on, }(\%)\end{array}$} & \multirow{2}{*}{$\begin{array}{l}\text { Laboratory } \\
\text { germination } \\
\text { on day } 7(\%)\end{array}$} & \multirow{2}{*}{$\begin{array}{l}\text { Percentage of } \\
\text { infested seeds }(\%)\end{array}$} & \multicolumn{3}{|c|}{ The population of seeds } \\
\hline & Day 3 & Day 5 & & & B. sorokiniana & D. teres & D. graminea \\
\hline Astana 2000 & 34.0 & 71.0 & 92.00 & 68.0 & +++ & ++ & + \\
\hline Preriya & 35.0 & 73.0 & 96.00 & 74.0 & +++ & ++ & + \\
\hline Donetskiy 8 & 57.0 & 94.8 & 96.50 & 27.0 & +++ & ++ & + \\
\hline Ilek 9 & 51.0 & 95.0 & 100.00 & 59.0 & +++ & + & + \\
\hline Symbat & 32.5 & 72.0 & 93.00 & 82.0 & ++ & + & + \\
\hline Arna & 46.0 & 88.3 & 94.00 & 84.0 & ++ & + & + \\
\hline Sever 1 & 32.0 & 79.0 & 96.00 & 63.0 & ++ & + & + \\
\hline$P$ value at $95 \%$ confidence interval & 0.01 & 0.01 & 0.03 & $<0.01$ & & & \\
\hline
\end{tabular}

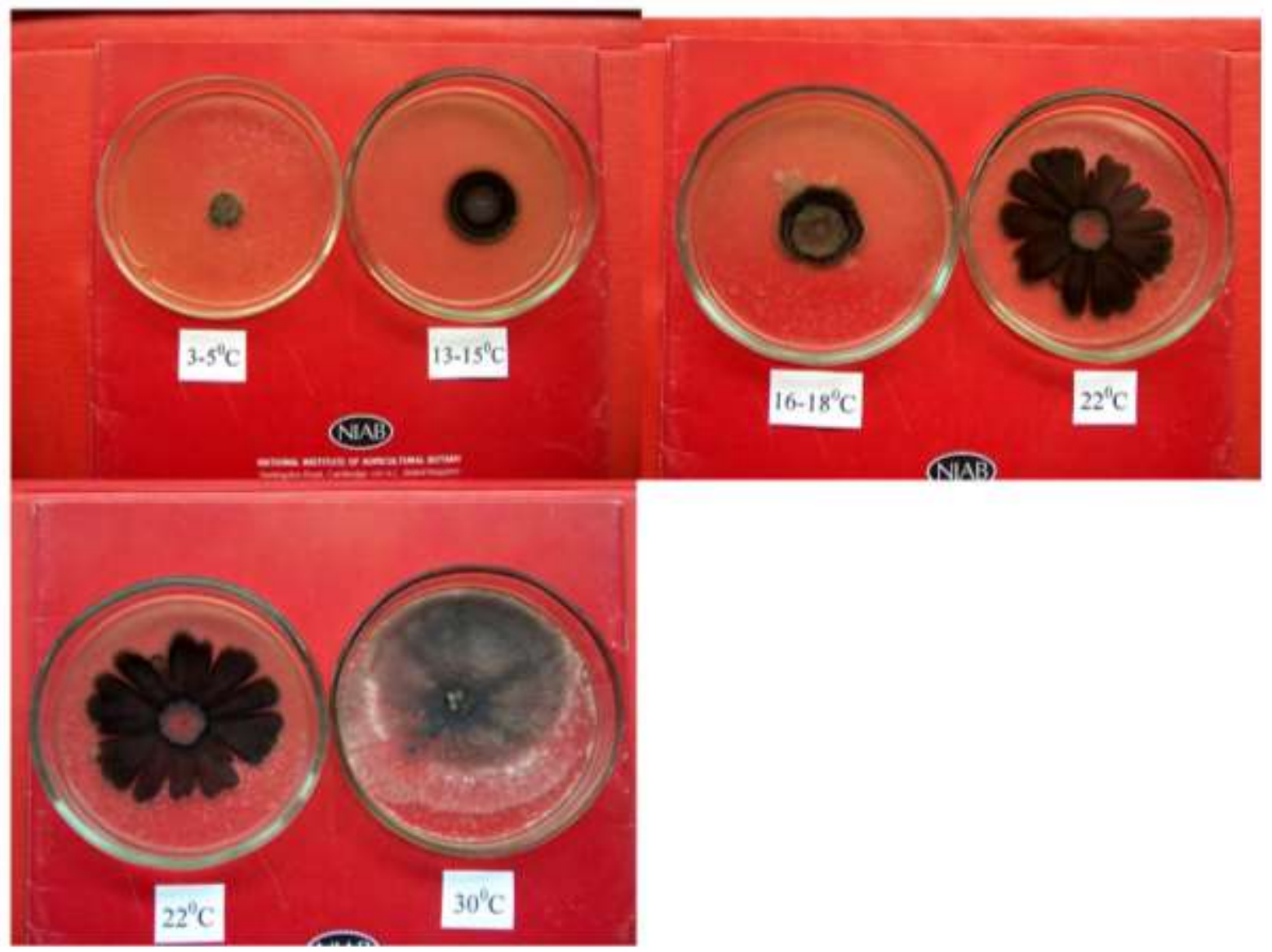

Fig. 1: Growth of a B. sorokiniana colony at different temperatures 


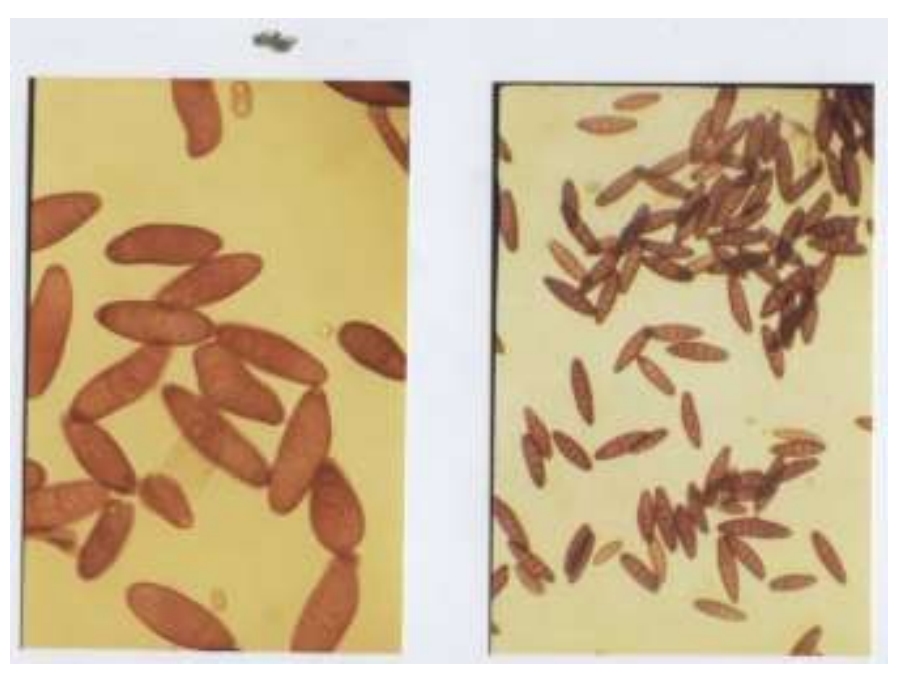

Fig. 2: B. sorokiniana conidium Kazakh Research Institute of Plant Protection and Quarantine, 2019

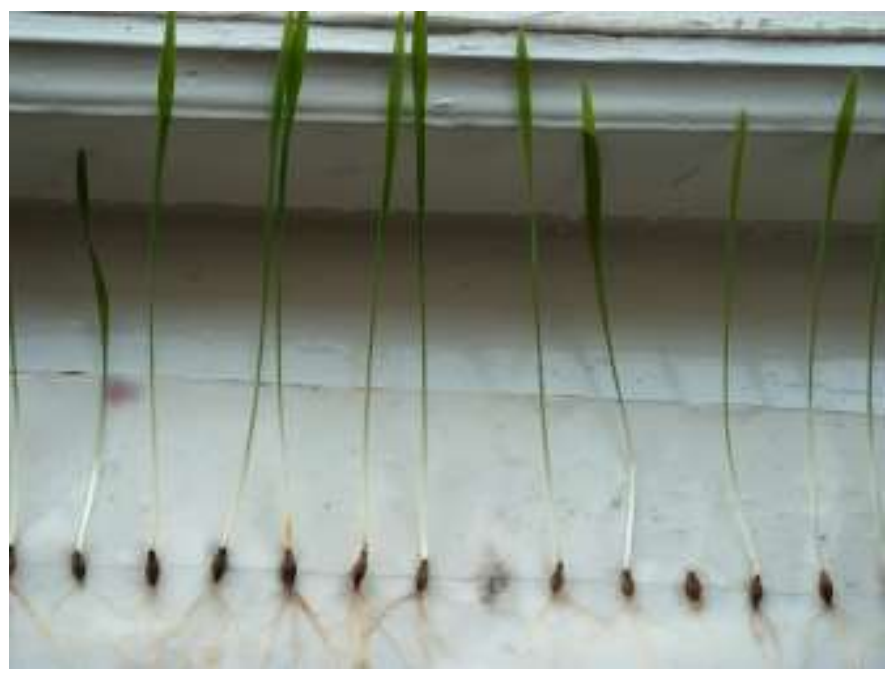

Fig. 3: The paper roll method for evaluating seed germination energy of barley Kazakh Research Institute of Plant Protection and Quarantine, 2019

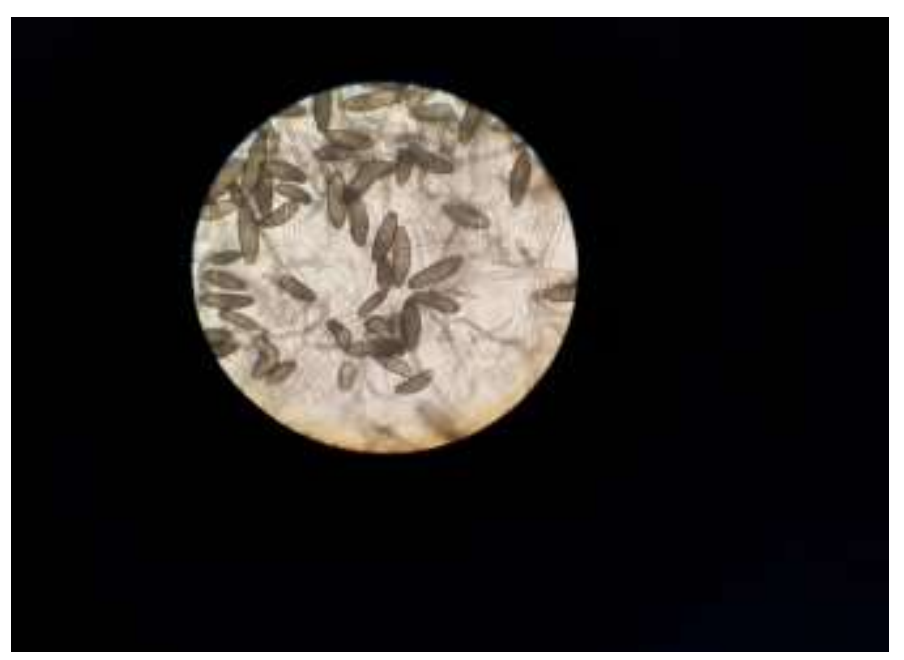

Fig. 4: D. graminea conidium Kazakh Research Institute of Plant Protection and Quarantine, 2019 


\section{Discussion}

According to (Bekezhanova, 2009), the most widespread barley diseases in the southeastern region of Kazakhstan are common root rot and dark brown spot (caused by $B$. sorokiniana), stripe disease $(D$. graminea), net blotch $(D$. teres) and bordered leaf blotch (R. secalis). She found that strains of the phytopathogenic fungi B. sorokiniana isolated from leaves of barley, rye and wheatgrass differed in morphological and cultural characteristics and pathogenic properties. B. sorokiniana can infect rye, barley and wheatgrass, possibly transferring them from rye to barley and wheatgrass and, accordingly, from wheatgrass to these crops.

On barley, the fungus Bipolaris sorokiniana can be found jointly with fungi from the genera Alternaria sp., Fusarium sp. and Penicillium sp. (Puchkova et al., 2020). According to our data, the occurrence of $B$. sorokiniana isolates on barley leaves in the foothills of the Almaty region was 6.5\%. It was found together with fungi from the genus Alternaria $(35.5 \%)$ and Drechslera graminea + Alternaria $(25 \%)$.

According to (Kumar and Rai, 2018), out of nine growth media (potato dextrose, Asthana Hawker's, Czapek's, Richards', malt extract, oatmeal, standard nutrients, cornmeal and wheat leaf decoction media) tested, oatmeal medium was the best-suited medium for radial growth and biomass production of Bipolaris sorokiniana as highest colony diameter, as well as dry mycelial weight was recorded on this media. For sporulation of Bipolaris sorokiniana, potato dextrose agar media was best as the highest numbers of spores $/ \mathrm{ml}$ were recorded in this media. According to our data, the optimal nutrient media for the cultivation of $B$. sorokiniana were determined-V4 medium, potato agar and Czapek's medium. The optimum temperature for the growth of fungal colonies was $22-30^{\circ} \mathrm{C}$.

Turuspekov et al. (2016) reported that genotyped a collection of barley of 92 commercial varieties and prospective lines, where resistance to stem rust was found in the field against an artificial infectious background of the Research Institute of Biological Safety Problems in the Zhambyl region of Kazakhstan. GLM analysis identified 15 SNPs associated with seeding time resistance (HA) and two SNPs associated with milky-wax seed maturity.

Rsaliyev et al. (2017) evaluated 107 isolates of the pathogen of powdery mildew from seven populations found on cultivated barley in two geographical points of Kazakhstan in 2015 and 2016. All isolates were virulent for the Mla8 resistance gene and avirulent for the Mla9, Mla 1 + Mla 2, Mla 6 + Mla14, Mla13 + MlRu3, Mla7 + MlNo3, Mla10 + MlDu2, Mla13 + MlRu3 and Mlo-5 resistance genes. There were 23 pathotypes with virulence complexity ranging from 1 to 6 . In all populations of the South Kazakhstan and Zhambyl regions, pathotypes 24 and 64 predominated.
Yield losses on cereal crops from leaf spots can increase depending on the cultivar's resistance to disease and weather conditions (Tamang et al., 2020; Surin et al., 2021). According to our data, in the Donetskiy 8 variety, the proportion of diseased seeds was 27\%, in Sever 1 and Ilek 9, it equaled 59-63\%, in Astana 2000 and Preriya, it amounted to $68-74 \%$ and in Symbat and Arna, it was $82-84 \%$.

\section{Conclusion}

We studied the morphological and cultural characteristics of fungi causing barley leaf spots, B. sorokiniana and $D$. graminea, in the South-East of Kazakhstan. The occurrence phytopathogenic fungi $B$. sorokiniana on barley leaves in the foothills of the Almaty region averaged $6.5 \%$. The fungi occurred more often with fungi from the Alternaria (35.5\%). D. graminea + Alternaria were found in $25 \%$ of the samples. We determined the optimal nutrient media for the cultivation of $B$. sorokiniana, namely the V4 medium, potato agar and Czapek's medium. The optimum temperature for the growth of fungi colonies equaled $22-30^{\circ} \mathrm{C}$.

D. graminea conidia isolated directly from leaves and grains had a statistically significant greater length, width and the number of septa compared to conidia grown on an artificial V4 nutrient medium. We described the morphological and cultural features of colonies of $B$. sorokiniana and $D$. graminea fungi on artificial nutrient media. The indicators of germination energy on days 3 and 5 differed statistically significantly: In the varieties Astana 2000 , Preriya and Symbat, it was $71-73 \%$ on day 5, in Sever, it equaled $79 \%$, in Arn, it was $88 \%$ and in the varieties Donetskiy 8 and Ilek 9 , it was at the level of $96-96.5 \%$.

\section{Acknowledgement}

The paper is based on the results obtained from project \# BR 06349590 "The creation of an agricultural technological park for precision farming" funded by the Ministry of Science and Education of the Republic of Kazakhstan.

\section{Author's Contributions}

All authors equally contributed in this work.

\section{Ethics}

This article is original and contains unpublished material. The corresponding author confirms that all of the other authors have read and approved the manuscript and no ethical issues involved

\section{References}

Agrios, G. N. (2005). Plant pathology. 5th Ed. Elsevier Academic Press, Burlington, MA. ISBN: 9780120445653, pp: 79-103. 
Aphalo, P. J. (2017). OpenIntro Statistics, by David M. Diez, Christopher D. Barr and Mine CetinkayaRundel. UV4Plants Bulletin. https://doi.org/10.19232/uv4pb.2016.2.90

Barbedo, J. G. A. (2019). Plant disease identification from individual lesions and spots using deep learning. Biosystems Engineering, 180, 96-107. https://www.sciencedirect.com/science/article/abs/pi i/S1537511018307797

Bekezhanova, M. (2009). Improving the methods for control of Helminthosporium and Rhynchosporium diseases on barley in southeastern Kazakhstan. The thesis of a Ph.D. dissertation, Almaty (in Kazakh). https://netrefs.ru/bekejanova-madina-melikiziazastanni-otstik-shifis-ajmafinda-a.html

Cadot, V., Villemot, J., Candresse, T., Marais, A., Bonnefoy, M., Schmitt, M., ... \& Rolland, M. (2017, May). Barley soil borne mosaic viruses: Identification of predominant viruses affecting yield and malting quality, in order to orientate breeding towards a sustainable resistance. In 12. European Foundation for Plant Pathology (EFPP); 10. French Society for Plant Pathology (SFP) Conference (pp. 236-p). https://hal.inrae.fr/hal-02736813

Dutbayev, Y., Islam, R., Haus, M. J., \& Day, B. (2020a). Impact of Fusarium infections on dry bean stomatal functions and crop physiology. Annals of Agri-Bio Research, 25(2), 270-274 http://agribiop.com/impact-of-fusarium-infectionson-dry-bean-stomatal-functions-and-cropphysiology/

Dutbayev, Y., Rametov, N., Tsygankov, V., Islam, R., \& Kuldubayev, N. (2020b). Linear modeling approach of physiological features of soybeans. EurAsian Journal of BioSciences, 14(2), 5555-5560. http://www.ejobios.org/article/linear-modelingapproach-of-physiological-features-of-soybeans8259.

FAO, IFAD, UNICEF, WFP, \& WHO (2018). The State of Food Security and Nutrition in the World 2018. Building climate resilience for food security and nutrition. FAO, Rome. http://www.fao.org/3/i9553en/i9553en.pdf

Faruk, M. I. (2019). Management of barley seedling disease caused by Sclerotium rolfsii through soil amendment with tricho-compost. European Journal of Biophysics, 7(1), 1-7. https://doi.org/10.11648/j.ejb.20190701.11

Gangwar, O. P., Bhardwaj, S. C., Singh, G. P., Prasad, P., \& Kumar, S. (2018). Barley disease and their management: An Indian perspective. Wheat and Barley Research, 10(3), 138-150. https://doi.org/10.25174/2249-4065/2018/83844
GRK. (2018). The State plan for the development of the agricultural complex of Kazakhstan for 2017-2021 (approved by the Decree of the Government of the Republic of Kazakhstan. Government of the Republic of

Kazakhstan. http://adilet.zan.kz/rus/docs/P1800000423

Harba, M., Jawhar, M., \& Arabi, M. I. E. (2020). In vitro Antagonistic Activity of Diverse Bacillus Species Against Cochliobolus sativus (Common Root Rot) of Barley. Acta Phytopathologica et Entomologica Hungarica, 55(1), 35-42. https://doi.org/10.1556/038.55.2020.012

Høyer, A. K., Jørgensen, H. J., Jensen, B., Murphy, B. R., \& Hodkinson, T. R. (2019). Emerging methods for biological control of barley diseases including the role of endophytes. Endophytes for a Growing World, 93. https://doi.org/10.1017/9781108607667.006

Kuldubayev, N., Dutbayev, Y., Lozowiska, B., \& Islam, R. (2020). The impact of soil infection of Fusariumequiseti and genotype to soybean physiology. Conference abstract, 60th scientific session, February 11-13, Institute of plant protection - national Research institute. Poznan, Poland. https://www.ior.poznan.pl/plik,3790,program-60sesji-naukowej-ior-pib-11-13-02-2020-pdf.pdf

Kumar, P., \& Rai, R. C. (2018). Effect of different growth media on radial growth, dry mycelial weight and sporulation of Bipolaris sorokiniana. https://www.entomoljournal.com/archives/2018/vol 6issue6/PartE/6-6-18-649.pdf

Lucas, J. A. (2020). Plant pathology and plant pathogens. John Wiley \& Sons.

Puchkova, E. P., Purlaur, V. K., Ivchenko, V. K., \& Mashkovskaya, N. A. (2020, August). Consequences of using seed fungicides on daughter seeds of barley. In IOP Conference Series: Earth and Environmental Science (Vol. 548, No. 5, p. 052065). IOP Publishing. https://iopscience.iop.org/article/10.1088/17551315/548/5/052065/meta

Rsaliyev, A., Pahratdinova, Z., \& Rsaliyev, S. (2017). Characterizing the pathotype structure of barley powdery mildew and effectiveness of resistance genes to this pathogen in Kazakhstan. BMC Plant Biology, 17(1), 1-11. https://link.springer.com/article/10.1186/s12870017-1130-3

Sagitov, A. O., Sultanova, N. Zh., Sarsenbaeva, G. B., Bekezhanova, M., Dzhaymurzina, A., \& Zhanuzakova, A. (2020). The effectiveness of treatment of soybean seeds with protective and stimulating compounds. Plant Protection and Quarantine, 8, 15-16 (in Russian). https://www.z-i-kr.ru/anons/aug20/aug20.htm 
Singh, D. P. (2017). Strategic disease management in wheat and barley. Management of wheat and barley diseases. Apple Academic Press, USA, 3-38.

Sooväli, P., Koppel, M., \& Kangor, T. (2017). Effectiveness of seed treatment against Fusarium spp. and Cochliobolus sativus of spring barley in different conditions. Argon. Research, 15(1), 280-287. https://agronomy.emu.ee/wpcontent/uploads/2017/03/Vol15Nr1_Soovali.pdf

Surin, N. A., Lipshin, A. G., Kozulina, N. S., Gerasimov, S. A., \& Vasilenko, A. V. (2021, March). Study of samples of spring barley from the collection of the All-Russian institute of crop production for resistance to biotic stress. In IOP Conference Series: Earth and Environmental Science (Vol. 677, No. 4, p. 042033). IOP Publishing. https://iopscience.iop.org/article/10.1088/17551315/677/4/042033/meta
Tamang, S., Kumar, S., Das, S., \& Mahapatra, S. (2020). Role of abiotic factors on disease progression of Spot blotch of Wheat. Indian Phytopathology, 1-7. https://link.springer.com/article/10.1007/s42360020-00280-5

Toropova, E. Y., Glinushkin, A. P., Selyuk, M. P., Kazakova, O. A., \& Ovsyankina, A. V. (2018). Development of soil-borne infections in spring wheat and barley as influenced by hydrothermal stress in the forest-steppe conditions of Western Siberia and the Urals. Russian Agricultural Sciences, 44(3), 241-244. https://link.springer.com/article/10.3103/S10683674 18030163

Turuspekov, Y., Ormanbekova, D., Rsaliev, A., \& Abugalieva, S. (2016). Genome-wide association study on stem rust resistance in Kazakh spring barley lines. BMC Plant Biology, 16(1), 13-21. https://bmcplantbiol.biomedcentral.com/articles/10. 1186/s12870-015-0686-Z 